\title{
Composition of the Mucopolymer in Cell Walls of the Unstable and Stable L-Form of Proteus mirabilis
}

\author{
By H. H. MARTIN \\ Institut für Angewandte Botanik, Technische Hochschule, München, Germany
}

(Received 28 April 1964)

\begin{abstract}
SUMMARY
Continuous, cell-shaped mucopolymer layers were isolated from cell walls of some unstable and stable L-forms of Proteus mirabilis. The chemical compositions of these non-rigid mucopolymers and of normal rigid mucopolymer basal-structures of rod-shaped Proteus bacteria were very similar. Electron microscopy showed that the protein and mucopolymer of the complex 'rigid layers' were organized differently in cell walls of rods and $L$-form cells. The results suggest that the rigid-layer protein plays a role in the morphogenesis of the mucopolymer.
\end{abstract}

\section{INTRODUCTION}

Great progress has recently been made in the elucidation of the structure of bacterial cell walls. It has been recognized that the rigid layer (R-layer) of the cell wall with its main component, the mucopolymer, plays an essential role in the maintenance of cell shape and rigidity (see Salton, 1960; Martin, 1963 $a$; Weidel \& Pelzer, 1964). This knowledge provides a chemical basis for understanding the processes which are at work during the conversion of rod-shaped bacteria into fragile globular spheroplasts and L-forms. Studies on the formation of penicillin-induced spheroplasts in some Gram-negative bacteria have shown that inhibition of mucopolymer biosynthesis and autolytic breakdown of the existing $R$-layers take place here (Salton \& Shafa, 1958; McQuillen, 1958; Leutgeb, Pelzer \& Schwarz, 1963). However, this interpretation does not seem to be applicable to some of the L-forms of Proteus mirabilis. Fragile walls of the unstable (reversible) L-form of Proteus, grown in penicillin medium, were shown to contain normal amounts of mucopolymer with the typical set of amino acids and amino sugars (Kandler, Hund \& Zehender, 1958; Martin, 1963b). Among the stable (non-reverting) Proteus L-forms Weibull (1958) and Morrison \& Weibull (1962) observed at least one strain, L9, which contained a considerable amount of the mucopolymer constituent diaminopimelic acid in the macromolecular cell fraction. It appears then that the mechanical defects of the L-form walls might not be caused by the inability to synthesize mucopolymer and to retain it in the cell walls, but rather by changes in the quantitative composition or in the macromolecular organization of the mucopolymer. The present paper describes the isolation of mucopolymer layers from cell walls of several L-forms and rod-shaped bacteria of $\boldsymbol{P}$. mirabilis and their characterization by chemica] analysis and electron microscopy. 


\section{METHODS}

Organisms. Strain vi of Proteus mirabilis and the stable Proteus L-strains $L V I$ and $L D 52$ were obtained from $O$. Kandler and had originally been received from U. Taubeneck. The unstable L-strain $1 \mathrm{Ca} /$ pen had been isolated in 1955 by Kandler \& Kandler (1956). It has been propagated since then by serial transfer on agar medium containing 200 international units (i.u.) penicillin/ml. Other strains of rod-shaped Proteus bacteria and of the stable $\mathbf{L}$-form were derived from the unstable strain $1 \mathrm{Ca} /$ pen in the course of the present work. Their isolation is described below in Results.

Growth conditions. Mass cultures of Proteus bacteria and L-forms were grown at $35^{\circ}$ in 81 . batches of vigorously aerated medium containing the following nutrients per litre: tryptic casein peptone (Merck, Darmstadt), 15 g.; beef extract (Brunnengräber, Lübeck), 15 g.; glucose, 2 g.; $\mathrm{NaCl}, 5$ g.; $\mathrm{Na}_{2} \mathrm{HPO}_{4}, 4.5$ g.; distilled water; adjusted to $\mathrm{pH} 7 \cdot \mathbf{0}$. Penicillin (200 i.u./ml.) was added to cultures of $1 \mathrm{Ca} / \mathrm{pen}$. The stable L-strains LVI and LD52 required the addition of $5 \%(v / v)$ defibrinated horse serum for good growth. Solid media for stock cultures and plating were prepared by adding agar $(1 \cdot 2 \%, w / v)$ to the medium. In mass cultures all organisms were grown until the beginning of the stationary phase, the organisms were then harvested in a continuous flow centrifuge, rapidly cooled and stored at $-20^{\circ}$.

Isolation of cell ralls. The conventional method of shaking organisms with glass beads in a Mickle type disintegrator and subsequent differential centrifugation (Salton \& Horne, 1951) was adequate for the isolation of cell walls from rod-shaped Proteus bacteria. The frozen cell paste was thawed and then vigorously stirred with DNAse (Worthington Biochemical Corp.) $0 \cdot 1 \mu \mathrm{g} . / \mathrm{ml}$. for $10 \mathrm{~min}$. at room temperature. The organisms were then treated in the Mickle apparatus suspended in a $0.8 \%(\mathrm{w} / \mathrm{v})$ solution of sodium dodecylsulphate in distilled water to preclude autolytic breakdown of the mucopolymer (Weidel, Frank \& Martin, 1960; Weidel, Frank \& Leutgeb, 1963). L-form organisms required no mechanical treatment for the separation of cell walls from the cytoplasmic constituents: after thawing and treatment with DNAse those cells were suspended in $0.8 \%(\mathrm{w} / \mathrm{v})$ sodium dodecylsulphate solution which caused rapid 'lysis', recognizable by complete clearing of the suspension within 30-60 sec. From the lysates empty or near-empty cell walls were sedimented by centrifugation for $35 \mathrm{~min}$. at $30,000 \mathrm{~g}$. Wall sediments were purified by six cycles of washings in distilled water and sedimentation in the centrifuge.

Isolation of mucopolymer layers. The cell-wall layers containing the mucopolymer were isolated from cell walls by means of the phenol extraction procedure of Weidel et al. (1960). Following this technique mucopolymer-containing rigid-layers (Rlayers) were easily separated from other cell-wall macromolecules in rod-shaped bacteria and $\mathbf{L}$-forms grown in the absence of penicillin. In contrast, mucopolymer layers of the unstable $\mathrm{L}$-form $1 \mathrm{Ca} /$ pen were very light and difficult to separate from the lipopolysaccharide. Repeated cycles of differential centrifugation at 60,000 g for $\mathbf{4 0} \mathrm{min}$. were required to achieve this separation.

Mucopolymer layers were freed from covalently attached protein by treatment with proteolytic enzymes (Martin \& Frank, 1962). Substrates (5 mg. dry weight/ml.) were incubated for $15 \mathrm{hr}$ at $37^{\circ}$ with either pepsin (Worthington Biochem. Corp.) 
$500 \mu \mathrm{g} . / \mathrm{ml}$. in $1 / 15 \mathrm{M}$-glycine $+\mathrm{HCl}$ buffer (pH 2.5) or trypsin (Worthington Biochem. Corp.) in 1/15 $\mathrm{M}-\mathrm{Na}_{2} \mathrm{HPO}_{4}$ solution.

Analyses of amino acids and amino sugars. Quantitative determinations of amino acids and amino sugars in hydrolysates of mucopolymer layers were made by ionexchange chromatography with an automatic amino acid analyser (Messrs Bender and Hobein, Munich) as described previously (Martin \& Frank, 1962). In preparations which contained large amounts of protein in addition to mucopolymer, methionine was oxidized by treatment with hydrogen peroxide (Dent, 1948) to prevent its interference with the peak of diaminopimelic acid. In these cases parallel runs with hydrogen-peroxide-treated and untreated samples had to be made for the determination of DAP and muramic acid, respectively, since hydrogen peroxide also causes the appearance of an unidentified artifact peak in the position of the muramic acid peak (after serine and before glutamic acid).

\section{RESULTS}

Isolation of stable L-forms and rod-shaped revertants from the unstable L-strain 1 Ca/pen of Proteus mirabilis

At the beginning of this work the unstable L-strain $1 \mathrm{Ca} /$ pen of Proteus mirabilis had been carried through about 300 weekly transfers on agar medium containing $200 \mathrm{i} . u$. penicillin $/ \mathrm{ml}$. In liquid aerated penicillin medium strain $1 \mathrm{Ca} /$ pen formed spherical forms of different size, average diameter from 1 to $4 \mu$. Young forms of still smaller size were seen to originate as buds from bigger forms. About $20 \%$ of the spheres were motile. Electron microscopic pictures (Pl. 1, fig. 1) showed forms whose surfaces were densely covered with loosely attached fimbriae and 'spheroidal surface matter' (Brinton, 1959). Some of the forms carried several flagella in a fashion resembling in part the peritrichous flagellation of normal Proteus bacteria.

When strain $1 \mathrm{Ca}$ /pen organisms were plated on penicillin-free nutrient agar very few of them reverted to normal rod-shaped bacteria. Instead, an assortment of colonies with considerable variety in cellular morphology was obtained. The great majority consisted of motile or non-motile organisms of still spherical shape but with sharply defined boundaries (Pl. 1, fig. 2). Pure cultures derived from isolated colonies of such 'stable L-forms' have been subcultured on penicillin-free medium for two years at monthly intervals and have shown no sign of reversion to the bacillary state during this period. These newly isolated stable L-forms closely resembled the original $1 \mathrm{Ca}$ /pen organism in cellular morphology as well as in fragility and sensitivity to osmotic shock.

A few colonies on the reversion plates consisted of oblong organisms of irregular size and shape, others of non-septate filaments of variable length or of regular nonmotile rods. Normal motile Proteus bacteria were never obtained from such platings. A detailed account of these observations will be given elsewhere. For further work on cell walls three strains derived from $1 \mathrm{Ca} /$ pen were selected: two stable $\mathrm{L}$-strains $(1 \mathrm{Ca} / 20,1 \mathrm{Ca} / 25)$ and one revertant strain $(1 \mathrm{Ca} / 5)$ with rod-shaped cells. 


\section{Isolation of cell walls from $L$-forms of Proteus mirabilis treated with sodium dodecylsulphate}

Previous observations have shown that the sensitivity of the cell walls of Gramnegative bacteria to disaggregation by an anionic detergent, such as sodium dodecylsulphate, depends on the state of the mucopolymer layer in the walls (Martin, unpublished observations; Weidel et al. 1963). The shape and rigidity of cell walls containing intact mucopolymer are not impaired by treatment with sodium dodecylsulphate. In contrast, walls whose mucopolymer has been degraded by autolysins or by lysozyme are rapidly disintegrated by this detergent. Thus, treatment with sodium dodecylsulphate provides a simple method for showing the presence of a continuous mucopolymer layer in a cell wall. When organisms of several L-strains were suspended in solutions of $0.4 \%(\mathrm{w} / \mathrm{v})$ sodium dodecylsulphate in distilled water different reactions were observed. Rapid clearing of the suspensions within a few seconds took place in all cases. In 'lysates' of the unstable L-strain $1 \mathrm{Ca} /$ pen and of the stable $\mathrm{L}$-strains $1 \mathrm{Ca} / 20$ and $1 \mathrm{Ca} / 25$ large quantities of empty cell walls were preserved in their original globular shape and size (Pl. 1, figs. 3, 4). Organisms of other stable strains (L VI, LD52) were dispersed completely into minute fragments. Entire empty cell walls were never recovered from the two latter organisms.

\section{The rigid layers in cell roalls of rod-shaped Proteus and the rigid layer equivalents of $L$-form cell walls}

Weidel et al. (1960) used a phenol extraction procedure to separate the three principal macromolecular components of the cell wall of Escherichia coli в: lipoprotein, lipopolysaccharide, rigid layer. When this technique was applied to isolated cell walls of the rod-shaped Proteus strain $1 \mathrm{Ca} / 5$ rigid layers were obtained whose appearance under the electron microscope was very similar to that of the R-layers described earlier for $\boldsymbol{E}$. coli В (Pl. 2, fig. 5). The surface of the Proteus R-layers was densely covered in the same characteristic manner with granular protein matter. This R-layer protein which, unlike the lipoprotein of the cell wall, was not removed by phenol, was solubilized only by treating the R-layers with trypsin or pepsin. Smoothsurfaced cell-shaped mucopolymer 'basal structures' were then obtained (Pl. 2, fig. 6).

When the phenol extraction procedure was applied to isolated cell walls of the unstable $\mathrm{L}$-form $1 \mathrm{Ca} /$ pen, protein + mucopolymer layers were recovered from which treatment with protease liberated heavily damaged mucopolymer membranes (Pl. 2, fig. 7). Yet in spite of their eroded appearance these membranes possessed enough mechanical stability to survive as individual particles, which roughly preserved the contours of the original L-forms. Likewise, bag-shaped rigid-layer equivalents were isolated by extracting cell walls of the stable L-forms $1 \mathrm{Ca} / 20$ and $1 \mathrm{Ca} / 25$ with phenol. These had a more solid texture than the structures present in the unstable L-forms. Before treatment with protease they also contained covalently associated protein and mucopolymer as main components. However, the arrangement of the protein which is typical for R-layers of rods, namely as a granular stratum covering the surface of the mucopolymer basal structure, was never observed here. Complex protein + mucopolymer layers and naked mucopolymer basal 
structures, from which the protein had been removed by protease, look very much alike under the electron microscope (Pl. 2, figs. 8, 9).

The isolated mucopolymers from rod-shaped Proteus and from the unstable and stable L-forms were all sensitive to lysozyme. As little as $10 \mu \mathrm{g}$. lysozyme $/ \mathrm{ml}$. in 1/20 M-ammonium acetate dissolved about $1 \mathrm{mg}$. dry weight/ml. of all different mucopolymers within a few minutes, leaving no structured residues recognizable in the electron microscope.

Table 1. Amino acids and amino sugars in 'rigid layers' of rod-shaped bacteria and $L$-form cells of Proteus mirabilis

Bacterial form

\begin{tabular}{|c|c|c|c|c|c|c|c|c|c|}
\hline \multicolumn{4}{|c|}{ Bacterial form } & \multicolumn{6}{|c|}{ L-form } \\
\hline \multirow{2}{*}{\multicolumn{2}{|c|}{$\begin{array}{c}\text { Proteus } \\
\text { mirabilis vi }\end{array}$}} & \multirow{2}{*}{\multicolumn{2}{|c|}{$\begin{array}{l}\text { Strain } \\
1 \mathrm{Ca} / 5\end{array}$}} & \multirow{2}{*}{\multicolumn{2}{|c|}{$\begin{array}{l}\text { Unstable } \\
\text { Strain } \\
1 \mathrm{Ca} / \text { pen }\end{array}$}} & \multicolumn{4}{|c|}{ Stable } \\
\hline & & & & & & $\begin{array}{l}\text { St } \\
1 \mathrm{C}\end{array}$ & $\begin{array}{l}\text { ain } \\
\text { a/20 }\end{array}$ & $\begin{array}{l}\text { Str } \\
1 \mathrm{C}\end{array}$ & $\begin{array}{l}\text { ain } \\
a / 25\end{array}$ \\
\hline$\%$ & $\begin{array}{l}\text { Molar } \\
\text { ratio }\end{array}$ & $\%$ & $\begin{array}{l}\text { Molar } \\
\text { ratio }\end{array}$ & $\%$ & $\begin{array}{l}\text { Molar } \\
\text { ratio }\end{array}$ & $\%$ & $\begin{array}{l}\text { Molar } \\
\text { ratio }\end{array}$ & $\%$ & $\begin{array}{l}\text { Molar } \\
\text { ratio }\end{array}$ \\
\hline $6 \cdot 8$ & $1 \cdot 00$ & $7 \cdot 8$ & $1 \cdot 00$ & $10 \cdot 7$ & $1 \cdot 00$ & $3 \cdot 1$ & $1 \cdot 00$ & $6 \cdot 4$ & $1 \cdot 00$ \\
\hline $10 \cdot 5$ & 2.04 & 8.9 & 1.52 & $9 \cdot 8$ & 1.22 & $5 \cdot 8$ & 2.52 & $8 \cdot 9$ & $1 \cdot 85$ \\
\hline $8 \cdot 1$ & $\mathbf{2 \cdot 8 6}$ & $7 \cdot 1$ & $2 \cdot 20$ & $8 \cdot 3$ & $1 \cdot 88$ & $\mathbf{3 \cdot 9}$ & $3 \cdot 06$ & $6 \cdot 6$ & $2 \cdot 49$ \\
\hline $4 \cdot 8$ & 0.51 & $8 \cdot 1$ & 0.77 & $10 \cdot 4$ & 0.72 & $2 \cdot 5$ & 0.59 & 4.5 & 0.52 \\
\hline $2 \cdot 7$ & 0.42 & $4 \cdot 6$ & $0 \cdot 64$ & $\mathbf{9} \cdot \mathbf{3}$ & 0.94 & 3.0 & 1.04 & $3 \cdot 2$ & 0.54 \\
\hline $6 \cdot 0$ & $1 \cdot 30$ & $3 \cdot 9$ & 0.75 & $4 \cdot 2$ & 0.59 & $4 \cdot 3$ & $2 \cdot 11$ & $5 \cdot 9$ & $\mathbf{1} \cdot \mathbf{3 7}$ \\
\hline $2 \cdot 6$ & $0 \cdot 64$ & $1 \cdot 6$ & $0 \cdot 35$ & $1 \cdot 6$ & $\mathbf{0 \cdot 2 6}$ & $1 \cdot 5$ & $0 \cdot 83$ & $\mathbf{2 \cdot 3}$ & $0 \cdot 61$ \\
\hline $2 \cdot 5$ & 0.72 & $\mathbf{2} \cdot \mathbf{2}$ & 0.57 & $1 \cdot 4$ & $0 \cdot 26$ & $\mathbf{2 \cdot 1}$ & $1 \cdot 35$ & $2 \cdot 6$ & 0.78 \\
\hline $2 \cdot 2$ & 0.95 & 0.9 & $0 \cdot 36$ & $\mathbf{1} \cdot \mathbf{3}$ & $0 \cdot 38$ & $1 \cdot 4$ & $1 \cdot 41$ & $1 \cdot 6$ & 0.74 \\
\hline $\mathbf{3} \cdot \mathbf{0}$ & 0.75 & $1 \cdot 3$ & $0 \cdot 29$ & $1 \cdot 2$ & $0 \cdot 19$ & $\mathbf{2 \cdot 2}$ & $1 \cdot 25$ & $2 \cdot 2$ & $0 \cdot 60$ \\
\hline $2 \cdot 4$ & 0.54 & $0 \cdot 8$ & $0 \cdot 16$ & 0.7 & $0 \cdot 10$ & $1 \cdot 3$ & 0.65 & 1.8 & 0.43 \\
\hline $4 \cdot 3$ & 0.96 & $2 \cdot 1$ & 0.40 & $1 \cdot 7$ & 0.25 & $3 \cdot 7$ & $1 \cdot 83$ & 3.7 & 0.88 \\
\hline $2 \cdot 9$ & 0.50 & $1 \cdot 0$ & $0 \cdot 13$ & $1 \cdot 1$ & $0 \cdot 11$ & $1 \cdot 5$ & 0.43 & $1 \cdot 6$ & $0 \cdot 26$ \\
\hline 1.5 & $0 \cdot 25$ & $1 \cdot 0$ & $0 \cdot 15$ & $2 \cdot 0$ & 0.22 & $1 \cdot 5$ & 0.56 & $2 \cdot 4$ & 0.43 \\
\hline 4.7 & 0.85 & $1 \cdot 4$ & 0.24 & $3 \cdot 8$ & 0.46 & $3 \cdot 0$ & $1 \cdot 30$ & $3 \cdot 4$ & 0.71 \\
\hline $\mathbf{3} \cdot 0$ & 0.49 & $1 \cdot 8$ & 0.25 & $3 \cdot 7$ & $\mathbf{0 . 3 8}$ & $2 \cdot 4$ & 0.85 & $2 \cdot 5$ & 0.43 \\
\hline $68 \cdot 0$ & 一 & $54 \cdot 5$ & $\longrightarrow$ & $71 \cdot 2$ & - & $43 \cdot 2$ & - & $59 \cdot 6$ & - \\
\hline
\end{tabular}

Diaminopimelic acid

Glutamic acid

Alanine

Muramic acid

Glucosamine

Aspartic acid

Threonine

Serine

Glycine

Valine

Isoleucine

Leucine

Tyrosine

Phenylalanine

Lysine

Arginine

Total \% of dry weight

Chemical composition of 'rigid layers' and mucopolymer basal structures from rods and $L$-forms of Proteus mirabilis

Quantitative determinations of amino acids and amino sugars were made on samples of rigid layers from two strains of rod-shaped bacteria (Proteus mirabilis vI and $1 \mathrm{Ca} / 5$ ) and on rigid-layer equivalents of unstable and stable $\mathrm{L}$-forms ( $1 \mathrm{Ca} / \mathrm{pen}$, $1 \mathrm{Ca} / 20,1 \mathrm{Ca} / 25)$. The results are summarized in Table 1 . In all preparations from rods and L-forms typical mucopolymer constituents and a number of 'unspecific' amino acids were found. An interesting difference was observed when liberation of the mucopolymers from the R-layers by means of proteolytic enzymes was attempted. Pepsin was more effective in solubilizing the R-layer protein than trypsin. However, in spite of prolonged enzyme treatment small amounts of amino acids of the order of a few percent adhere tenaciously to all those mucopolymer preparations from rods or from stable L-forms which were formed in the absence of penicillin. In contrast, mucopolymer of the unstable $\mathrm{L}$-form $1 \mathrm{Ca} /$ pen was completely freed from unspecific amino acids by trypsin (Table 2 ). 
Obviously, none of the different basal structure preparations was free from contaminating cell material. Mucopolymer yields were lower in the preparations from the stable L-forms where no effort could be made to apply mechanical methods for obtaining purer cell walls as a starting material. For the same reason no exact figures on yields of cell walls from L-forms can be given now beyond the general statement that, according to microscopic observation, one cell wall and one mucopolymer membrane are obtained from each L-form organism.

Table 2. Amino acids and amino sugars of mucopolymer basal-structures from bacterial and $L$-forms of Proteus mirabilis

Mucopolymer from unstable L-form $1 \mathrm{Ca} /$ pen after treatment with trypsin; all others after treatment with pepsin.

Bacterial form

L-form

Diaminopimelic acid

Glutamic acid

Alanine

Muramic acid

Glucosamine

Aspartic acid

Threonine

Serine

Glycine

Valine

Isoleucine

Leucine

Tyrosine

Phenylalanine

Lysine

Arginine

Total \% of dry weight

\begin{tabular}{|c|c|c|c|c|c|c|c|c|c|}
\hline & 年 & 10014 & & & & & ) & & \\
\hline & & & & Uns & able & & Stabl & & \\
\hline $\begin{array}{r}P r \\
\text { mira }\end{array}$ & $\begin{array}{l}\text { teus } \\
\text { ilis vI }\end{array}$ & & ain & $\begin{array}{r}\mathrm{St} \\
1 \mathrm{C} \varepsilon\end{array}$ & $\begin{array}{l}\text { ain } \\
\text { /pen }\end{array}$ & St & ain & $\begin{array}{l}\text { St } \\
1 \mathrm{C}\end{array}$ & ain \\
\hline$\%$ & $\begin{array}{l}\text { Molar } \\
\text { ratio }\end{array}$ & $\%$ & $\begin{array}{c}\text { Molar } \\
\text { ratio }\end{array}$ & $\%$ & $\begin{array}{c}\text { Molar } \\
\text { ratio }\end{array}$ & $\%$ & $\begin{array}{c}\text { Molar } \\
\text { ratio }\end{array}$ & $\%$ & $\begin{array}{c}\text { Molar } \\
\text { ratio }\end{array}$ \\
\hline $13 \cdot 4$ & $1 \cdot 00$ & $11 \cdot 7$ & 1.00 & $12 \cdot 9$ & 1.00 & $8 \cdot 8$ & 1.00 & $11 \cdot 0$ & 1.00 \\
\hline $11 \cdot 0$ & $1 \cdot 10$ & $10 \cdot 2$ & $1 \cdot 16$ & $10 \cdot 0$ & $1 \cdot 04$ & $7 \cdot 3$ & $1 \cdot 10$ & $8 \cdot 1$ & 0.99 \\
\hline $10 \cdot 6$ & 1.91 & $9 \cdot 0$ & 1.87 & $9 \cdot 1$ & $1 \cdot 71$ & $6 \cdot 3$ & 1.73 & 6.7 & $1 \cdot 50$ \\
\hline $15 \cdot 8$ & 0.87 & $15 \cdot 2$ & 0.96 & $16 \cdot 7$ & 0.96 & $1 \cdot 9$ & 1.00 & 11.5 & 0.77 \\
\hline $11 \cdot 8$ & 0.95 & $11 \cdot 3$ & 1.04 & $12 \cdot 1$ & 1.01 & 9.5 & $1 \cdot 16$ & $9 \cdot 4$ & 0.92 \\
\hline $0 \cdot 6$ & 0.06 & $1 \cdot 2$ & $0 \cdot 15$ & - & - & 1.0 & $0 \cdot 18$ & 1.0 & 0.13 \\
\hline $0 \cdot 3$ & 0.04 & 0.5 & 0.07 & - & 一 & 0.5 & 0.09 & 0.5 & 0.06 \\
\hline 0.6 & 0.08 & 0.7 & $0 \cdot 12$ & - & - & $1 \cdot 0$ & $0 \cdot 23$ & 0.9 & $0 \cdot 16$ \\
\hline 0.4 & 0.08 & $0 \cdot 6$ & $0 \cdot 15$ & - & - & 0.7 & $0 \cdot 23$ & 0.5 & $0 \cdot 15$ \\
\hline- & - & - & - & - & 一 & - & - & - & - \\
\hline 0.2 & 0.02 & 0.4 & 0.05 & - & - & 0.4 & 0.07 & 0.3 & 0.04 \\
\hline 0.3 & 0.03 & 0.6 & 0.08 & - & - & 0.8 & $0 \cdot 14$ & 0.7 & 0.09 \\
\hline $1 \cdot 2$ & $0 \cdot 10$ & $1 \cdot 2$ & $0 \cdot 11$ & - & 一 & 1.0 & $0 \cdot 12$ & 1.4 & $0 \cdot 13$ \\
\hline 一 & 一 & - & - & - & - & - & - & - & - \\
\hline - & - & - & - & - & - & - & - & - & - \\
\hline 一 & - & - & - & 一 & - & - & - & - & - \\
\hline 66.2 & - & $62 \cdot 6$ & - & 60.8 & - & $49 \cdot 2$ & - & 52.0 & - \\
\hline
\end{tabular}

Absence of mucopolymer from the stable $L$-form strains $\mathrm{L}$ VI and LD52 of Proteus mirabilis

The disappearance of any insoluble structures resembling cell walls from sodium dodecylsulphate-lysates of the stable L-strains L VI and L D52 strongly suggested that the integuments of this kind of L-form of Proteus mirabilis are altogether differently organized. It seems most likely that no covalently interlinked basal structures are present here. It remained to investigate whether organisms of this L-form have incomplete cell walls containing only separate islets of mucopolymer; they might also be completely devoid of mucopolymer or other cell-wall material. The search for mucopolymer was done on hydrolysates of entire organisms of strains LVI and LD52 and also on the small-particle fractions which remained insoluble after lysis with sodium dodecylsulphate, and which were suspected of harbouring mucopolymer fragments. Wet cell sediments of strains L VI and LD52 were frozen and thawed, the paste stirred vigorously for $10 \mathrm{~min}$. with DNAse and then lysed in a $0 \cdot 4 \%(\mathrm{w} / \mathrm{v})$ solution 
of sodium dodecylsulphate in distilled water; insoluble material was sedimented from the lysates by centrifugation for $1 \mathrm{hr}$ at $100,000 \mathrm{~g}$. The jelly-like sediments were extracted with phenol and the insoluble fractions washed free from phenol with water and freeze-dried. Samples were analysed for amino acids, amino sugars and neutral sugars. Yields of phenol-insoluble matter were $9 \%$ dry weight from strain LD52 and $19 \%$ from strain LVI. The substance from LD52 contained small amounts of unspecific amino acids but not mucopolymer components such as diaminopimelic acid or muramic acid, nor neutral sugars. This material was not further characterized. Mucopolymer constituents were not present in the phenolinsoluble fraction of strain LVI. Components identified by solvent extraction and paper chromatography of hydrolysates were: lipid, galactose, glucose, glucosamine. From this evidence and from the typical appearance of the substance in the electron microscope (see Weidel et al. 1960) it is tentatively classified as a lipopolysaccharide. Lipopolysaccharides containing the same sugars have been found in the cell walls of all other investigated Proteus mirabilis strains of either rod or L-form, during the isolation of rigid layers by the phenol procedure.

The search for mucopolymer components in hydrolysates of total cell material of strains LD52 and LVI gave entirely negative results. Several sets of samples (20 $\mathrm{mg}$. dry weight) were run on the automatic amino acid analyser. Diaminopimelic acid and muramic acid were looked for in separate samples, with and without oxidation of methionine before application to the ion exchange column (see Methods). No peaks corresponding to diaminopimelic acid or muramic acid were found in any analysis. Since as little as $1 / 20 \mu$ mole diaminopimelic acid can be readily detected by our method, organisms of strains LD52 and LVI must contain less than $0.04 \%$ $(\mathrm{w} / \mathrm{w})$ diaminopimelic acid, if any. In contrast, the diaminopimelic acid content determined for bacillary Proteus mirabilis strain vi and the unstable L-form $1 \mathrm{Ca} /$ pen were $0 \cdot 16 \%$ and $0 \cdot 4 \%$ respectively (Martin, $1963 b$ ).

\section{DISCUSSION}

A paraphrase of Weidel's remark about bacterial cell walls (Weidel et al. 1963) would serve as the most appropriate characterization of the stable L-forms of Proteus mirabilis: 'An L-form is not an L-form, is not an L-form.' Conflicting reports about the presence or absence of mucopolymer components in stable L-forms (Weibull, 1958; Morrison \& Weibull, 1962; Kandler \& Zehender, 1957; Kandler et al. 1958) can be most easily understood by assuming that stable L-form strains with similar morphology but very different cell-wall structure were investigated in these cases. The available evidence strongly favours the view that stable L-forms of $\boldsymbol{P}$. mirabilis constitute a heterogeneous group of organisms. Within this group the complex enzymic apparatus responsible for the synthesis of the various macromolecular components of the cell wall must be blocked at very different stages. Proteus L-form strains of the type of LD52, LVI, the type A and c strains of Kandler \& Zehender (1957) and perhaps also strain L 18, studied by Morrison \& Weibull (1962), do not possess any mucopolymer. Our results suggest indeed that strain LD52 is completely devoid of any cell-wall material and thus represents a culture of true protoplasts which are able to multiply indefinitely, unlike the non-viable lysozyme protoplasts of Gram-positive bacteria (McQuillen, 1960). 
Proteus L-form strain LVI seems to retain at least one of the plastic cell-wall layers, the lipopolysaccharide. This finding is not necessarily in conflict with Taubeneck's observation on the absence of bacteriophage receptors from strain L vi (Taubeneck, 1961). It is not known whether or not lipopolysaccharide acts as phage receptor in Proteus, as it does for the phages T3, T4 and T7 in Escherichia coli в. Moreover, the $\mathbf{L}$-form lipopolysaccharide might have lost its receptor function as has happened with the lipopolysaccharide receptor analogue in the cell walls of phage-resistant $\boldsymbol{E}$. coli в/3, 4, 7 (see Weidel, 1958).

Stable L-forms of the type of Proteus strains $1 \mathrm{Ca} / 20$ and $1 \mathrm{Ca} / 25$, which incorporate continuous but non-rigid mucopolymer basal structures in their cell walls, have not been studied extensively before. Chemical data on such mucopolymers do not offer support for the supposition that the mechanical defects are caused by a specific inability to synthesize any single mucopolymer constituent, as happens for instance in the diaminopimelic acid-less mutants of Escherichia coli (Baumann \& Davis, 1957; McQuillen, 1958). Mucopolymers found in rodshaped Proteus bacteria and in stable and unstable L-forms of Proteus are of a remarkably similar composition. Molar ratios of building blocks generally range around the values: muramic acid:glucosamine:diaminopimelic acid:glutamic acid: alanine $=1: 1: 1: 1: 1 \cdot 7$. Thus, Proteus mucopolymers closely resemble mucopolymers previously found in some other Gram-negative bacteria (Martin \& Frank, 1962; Weidel et al. 1963). Another common feature of rigid layers in these enteric-bacteria is the covalent bonding of a protein component to the mucopolymer basal structure.

It is significant that mucopolymer-containing stable L-forms arise from the particular type of unstable L-form occurring in Proteus. In the latter organism the consequences of penicillin action observed in other bacteria, namely inhibition of mucopolymer synthesis (Park \& Strominger, 1957) and autolytic removal of mucopolymer from cell walls (Weidel et al. 1960; Leutgeb et al. 1963), are definitely not operative. Here, the penicillin seems to act more specifically, presumably by preventing the formation of certain cross-linkages within the mucopolymer which are indispensable for the establishment of shape and mechanical stability. Studies on the nature and amount of some cross-linkages in different Proteus mucopolymers will be described later.

It remains for further studies to explore how the originally reversible lesions which penicillin induces in the mucopolymer of unstable L-forms of Proteus become perpetuated as hereditary defects in the mucopolymer-synthesizing stable L-form. In this type of L-form (which we propose to call 'spheroplast L-form', in contrast to the 'protoplast L-forms' which are essentially without cell walls) construction of the rigid layer must be blocked at a late stage, involving the morphogenesis of the $\mathbf{R}$-layer rather than synthesis of its structural polymer. In this context the different ways of attachment of the protein component in the various R-layers to the mucopolymer basal structure, as seen in the electron microscope, should be noted. The typical surface pattern of protein granules is present only in rod-shaped rigid layers. No regular organization of the $R$-layer protein can be recognized in any of the nonrigid defective 'R-layers' of the L-forms. A useful working hypothesis for further studies might be to assume that the R-layer protein has an important function in the morphogenesis of the mucopolymer. In normal, bacillary organisms this function 
might be closely related to the specific spatial arrangement of the protein within the R-layer complex. Disorganization of this arrangement brought about by the toxic action of penicillin or by the acquisition of hereditary structural defects of a yet unknown nature might render the R-layer protein incapable of carrying out its normal function of disposing the synthesized mucopolymer into a rigid rod-shaped basal structure.

Thanks are due to Professor O. Kandler for his continued support and encouragement.

This work was supported by a grant from the Deutsche Forschungsgemeinschaft. The author is greatly indebted to Dr P. H. Hofschneider and Miss Anneliese Preuss for their help in producing the electron micrographs. The technical assistance of Miss Karen Stermose and Mrs Renate Beck is gratefully acknowledged.

\section{REFERENCES}

Baumann, N. \& Davis, B. D. (1957). Selection of auxotrophic bacterial mutants through diaminopimelic acid or thymine deprival. Science, 126, 170.

Brinton, C. C. (1959). Non-flagellar appendages of bacteria. Nature, Lond. 183, 782.

Dent, C. E. (1948). A study of the behaviour of some sixty ninhydrin reacting substances on phenol-collidine filter paper chromatography. Biochem.J. 43, 168.

Kandler, O. \& Kandler, G. (1956). Trennung und Charakterisierung verschiedener L-Phasentypen von Proteus vulgaris. $Z$. Naturforsch. 11 b, 252.

Kandler, O. \& Zehender, C. (1957). Ueber das Vorkommen von Diaminopimelinsäure bei verschiedenen L-Phasentypen von Proteus vulgaris und bei den pleuropneumonieähnlichen Organismen. Z. Naturforsch. $12 b, 725$.

Kandler, O., Hund, A. \& Zehender, C. (1958). Cell wall composition in bacterial and L-forms of Proteus vulgaris. Nature, Lond. 181, 572.

Leutgeb, W., Pelzer, H. \& Schwarz, U. (1963). Struktur und Stoffwechsel von E. coliStützmembranen. Zbl. Bakt. (1. Abt. Orig.), 191, 400.

Martin, H. H. \& Frank, H. (1962). Quantitative Bausteinanalyse der Stützmembran von Escherichia coli в. Z. Naturforsch. 17, 190.

MarTin, H. H. (1963a). Bacterial protoplasts-a review. J. theoret. Biol. 5, 1.

MaRTIN, H. H. $(1963 b)$. Zusammensetzung der Stützmembran in der Zellwand von normalen Zellen und Penicillin-Sphäroplasten von Proteus mirabilis. Zbl. Bakt. (1. Abt. Orig.), $191,409$.

McQuillen, K. (1958). Lysis resulting from metabolic disturbance. J. gen. Microbiol. $18,498$.

McQuillen, K. (1960). Bacterial protoplasts. In The Bacteria, ed. by I. C. Gunsalus \& R. Y. Stanier, vol. 1. New York and London: Academic Press.

Morrison, T. H. \& Weibull, C. (1962). The occurrence of cell wall constituents in stable Proteus-L-forms. Acta path. microbiol. scand. 55, 475.

Park, J. T. \& Strominger, J. L. (1957). Mode of action of penicillin. Science, 125, 99.

SAlton, M. R. J. \& HoRne, R. W. (1951). Methods of preparation and some properties of cell walls. Biochim. biophys. Acta, 7, 177.

Salton, M. R. J. \& Shafa, F. (1958). Some changes in the surface structure of Gramnegative bacteria induced by penicillin action. Nature, Lond. 181, 1321.

Salton, M. R. J. (1960). Microbial Cell Walls. New York, London: John Wiley and Sons Inc.

Taubeneck, U. (1961). Die Phagenresistenz der stabilen L-Form von Proteus mirabilis. Z. Naturforsch. $16 b, 849$.

Weibull, C. (1958). Chemical analyses elucidating the structure of bacterial L-forms. Acta path. microbiol. scand. 42, 324.

WeIDEL, W. (1958). Bacterial viruses. A. Rev. Microbiol. 12, 27. 
Weidel, W., Frank, H. \& Martin, H. H. (1960). The rigid layer of the cell wall of Escherichia coli strain B. J. gen. Microbiol. 22, 158.

Weidel, W., Frank, H. \& Leutgeb, W. (1963). Autolytic enzymes as a source of error in the preparation and study of Gram-negative cell walls. J. gen. Microbiol. 30, 127 .

Weidel, W. \& Pelzer, H. (1964). Bag-shaped macromolecules-a new outlook on bacterial cell walls. Adv. Enzymol. (in the press).

\section{EXPLANATION OF PLATES}

Plate 1

Fig. 1. Proteus mirabilis. Unstable L-form, strain $1 \mathrm{Ca}$ /pen. Flagellated spherical cell covered with fimbriae and loosely attached superficial cell wall material. Magnification, $\times 14,000$.

Fig. 2. Proteus mirabilis. Stable L-form, strain $1 \mathrm{Ca} / 20$. Organisms with sharply defined surface, sparsely covered with slender fimbriae. Magnification, $\times 14,700$.

Fig. 3. Proteus mirabilis. Unstable L-form, strain $1 \mathrm{Ca} /$ pen. Empty cell wall after lysis with $0 \cdot 4 \%$ $(w / v)$ sodium dodecylsulphate. Magnification, $\times 16,800$.

Fig. 4. Proteus mirabilis. Stable L-form, strain $1 \mathrm{Ca} / 20$. Cell walls left after lysis with sodium dodecylsulphate. Magnification, $\times \mathbf{1 6 , 8 0 0}$.

\section{Plate 2}

Fig. 5. Rod-shaped Proteus strain $1 \mathrm{Ca} / 5$. Rigid layers, isolated from cell walls by extraction with phenol. Magnification, $\times 18,000$.

Fig. 6. As in fig. 5. Mucopolymer basal structure obtained by treatment of rigid layer with pepsin. Magnification, $\times \mathbf{2 1 , 6 0 0}$.

Fig. 7. Proteus mirabilis. Unstable L-form, strain $1 \mathrm{Ca} /$ pen. Mucopolymer basal structures isolated from cell walls by extraction with phenol and treatment with trypsin. Magnification, $\times 18,000$.

Fig. 8. Proteus mirabilis. Stable L-form, strain $1 \mathrm{Ca} / 20$. Rigid-layer equivalent isolated from cell walls by phenol extraction. Magnification, $\times 21,600$.

Fig. 9. As in fig. 8. Mucopolymer basal structure, obtained by trypsin treatment of R-layer equivalent. Magnification, $\times \mathbf{2 1 , 6 0 0}$. 


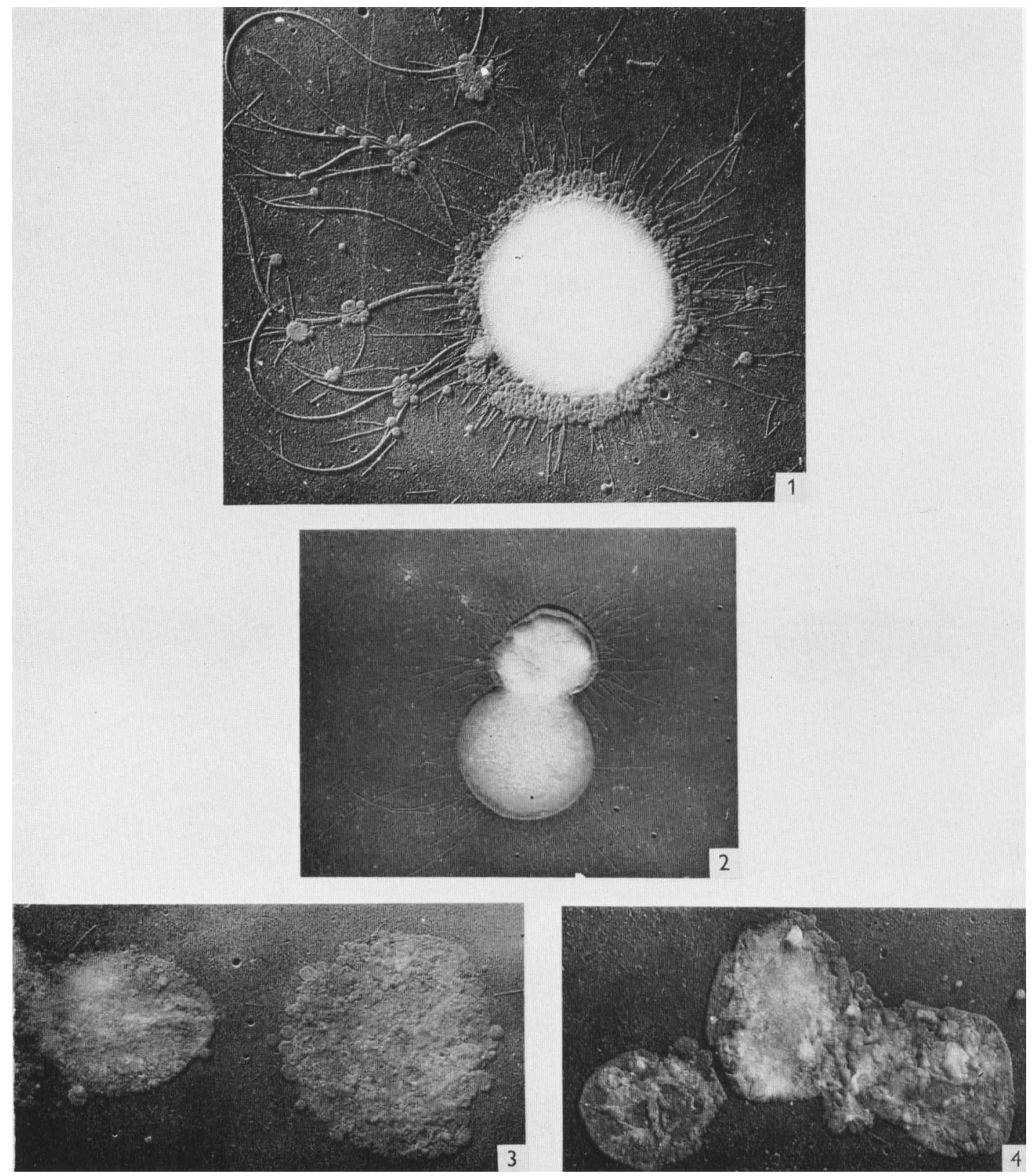


Journal of General Microbiology, Vol. 36, No. 3

Plate 2
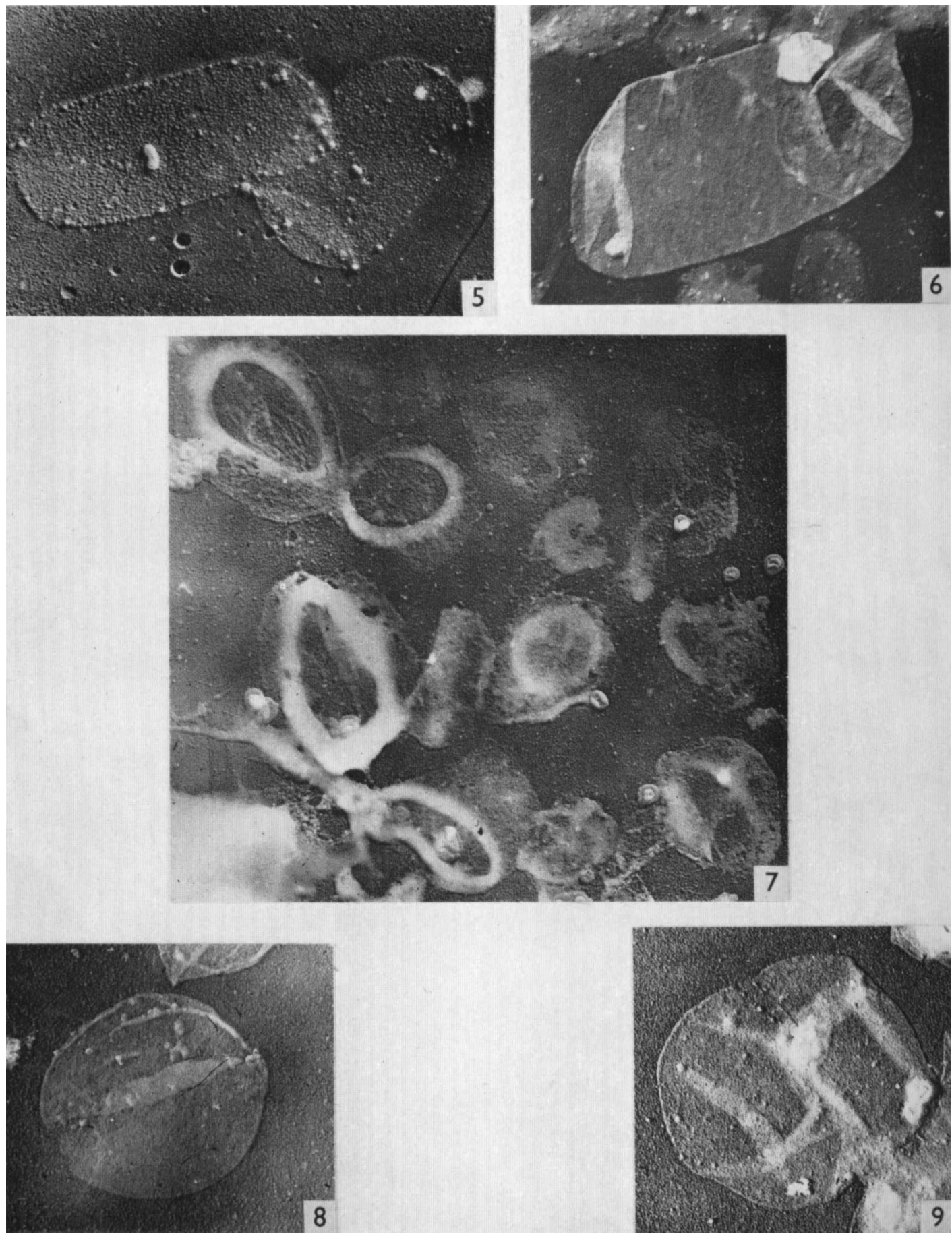

H. H. MARTIN 